\title{
ネズミチフス菌フアージの腸炎菌感染
}

\author{
服部保樹*

\section{YASUKI HATTORI : INFECTION OF SALMONELLA ENTERITIDIS WITH PHAGES FROM SALMONELLA TYPHIMURIUM}

\author{
〔受稿９月28日１960】
}

\begin{abstract}
序
著者の教室では腸炎菌のマウス感染による実験チフ ス症の研究が多年にわたり行われているが，本論文 において報告する研究も，晹炎菌の毒力を遺伝学的に 追求する目的をもつて始められたものである。すなわ ち，その法の一つとして，腸炎菌の强毒株から弱毒 株へ毒力を導入 (transduction: Zinder and Lede rberg，1952）によつて伝えることを計画したのであ るが，そのために必要なテンペレート・ファージの分 離に容易に成功しなかうたのであつた。ところがネズ ミチフス菌のある株の放出するテンペレート・ファー ジが非常に低い e.o.p. で腸炎菌に感染し，プラック を形成することを見出し，このプラックから分離した ファージは腸炎菌とネズミチフス菌とにほほ等しい e. o. p. をもつことがわかつた。このファージを腸炎 菌でくりかえしふやしても，あまり高い titer が得ら れないために，導入，ことに毒力の導入の実験には不 適当と考えられたので，ネズミチフス菌でふやしたフ アージをいきなり腸炎菌に感染させて栄養要求性に関 する導大をこころみたところ，上にのべたように e. o. p. は非常に低いにもかかわらず，高い頻度で導人 を諗めることができた。

そこで導入が行われる以上，感染が成立していると 考えられるのであるが，それにもかかわらず溶菌が極 めて低い頻度にしか見られないのは，いかなる理由に よるのであろうか。この点を検討した結果をここに報 告したいと思う。
\end{abstract}

\section{材 料と方法}

菌株: 腸炎菌 (Salmonella enteritidis) No. 11株 (教室保存)。ネズミチフス菌 (Salmonella typhim- urium) variant Copenhagen S-12株（北里研究所 合田博士から分与され分与された)，および LT-2株 (Carnegie 研究所 Demerec 博士から分与された). No. 11株はO抗原 [9, 12]をもち， S-12株はO抗原

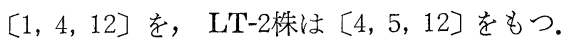

導入の実験には LT-2 株に由来する栄養素要求変異 株 (auxotroph) meth-6 (meth-) および try D-10 $\left.(\operatorname{try})^{-}\right)$と No. 11株から得られた栄養素要求変異株 E-19 (his-), E-49 (lys-) を recipientとして使用し た。 LT-2の変異株は Demerec 博土から分与された ものであり，No. 11の変異株は著者の教室の徐繁芝博 土がペニシリン・スクリーニング法により分離したも のである。

ファージ株：P-22 およびその virulent mutant H-4 および H-5（すべて Demerec 博士から分与さ れたもの)。また，著者は S-12株が溶原株であること を見出し，この株から分離したテンペレート・ファー ジを S-12ファージと名づけて使用した。

培地：普通ブイヨンおよび 普通寒天培地（ともに $\mathrm{pH}$ 7.4). Davis and Mingioli (1950) の minimal medium.

ファージの titration : Adams (1950) の方法によ つた。

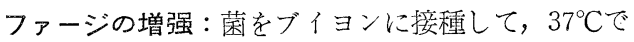
rotary shaker で軽く振りながら培養し，その対数 増殖期においてファージを加え，なるべく高い titer を得るようにつとめた。適当な時期に遠心沈澱 $(4,000$ 回転30分）によつて菌体を除き，上清にクロロフォル ムを加えたものをファージ液として使用した。

溶原化の方法：P-22ファージの原液に，ブイヨン で色々に稀彩した菌液を等量加え， $37^{\circ} \mathrm{C}$ で20分間振つ た後，その $0.1 \mathrm{ml}$ を寒天平板の表面にめり，1夜培

* 慶氾義熟大学医学部細菌学教室（指導 牛場大蔵教授） 
養後生じたコロニーについて溶原性を検査した。

溶原性の検查方法 : P-22 ファージの virulent mutant である H-5 ファージの高い titer (約 $10^{11} / \mathrm{ml}$ ) のもの $0.2 \mathrm{ml}$ を寒天平板の表面にぬつておき，その 上に検査すべき菌を劃線し，ファージをめつてない対 照の平板にも同椂に劃線して，1夜培養後，対照に比 較して全く溶菌されないものを溶原性とし，これにつ いてはさらにブイヨン培養上清について，ファージ産 生をしらべた。

ファージ吸着能の検查方法：Adams (1959) の方 法にしたがつた。すなわち，約 $10^{8} / \mathrm{ml}$ の対数増殖期 の菌液（あらかじめ作製した生菌数——比濁曲線で混 濁度から生菌数をしる）に約 $10^{8} / \mathrm{ml}$ のファージ夜を 加え， $37^{\circ} \mathrm{C}$ で軽く振り，5分毎に $0.1 \mathrm{ml}$ の材料をと り，直ちにクロロフォルム含有生理食塩水 $10 \mathrm{ml}$ に加 えてよくまぜる。この材料について遊離ファージの数 をしらべた。

ファージの一段階増殖実験：Adams (1959) の方 法にしたがつた，但し，抗ファージ血清の使用を省略 したいわゆる preliminary の方法を用いた。

導入の方法：Demerec et al. (1956) の方法に よつた. abortive transduction の検出には Ozeki （1956）の方法を用いた。

O（1）抗原の検出法：O (1) 血清（著者の教窒の 深沢学士が作つたもの）を用いてスライド凝集反応に より０(1) 抗原を検出した.ファージ感染後速やかに 出現する 0 (1) 抗原は, Uetake et al. (1958) の方 法によつて検出した。

\section{成 績}

ネズミチフス囷 LT-2 株又は腸炎囷 No. 11株でふや したファージのLT-2株および No. 11株での e. o. p.

結果の一部を第 1 表に示したが，この表に見られる 様に，P-22, H-5, H-4, S-12，何れのファージも，LT-2 でふやしてから，LT-2. No.11で titrationを行う と，No.11での e. o. p. は LT-2 に比して約10-4に すぎないことがわかつた。次にこれらのファージを No. 11でふやすを，その e. o. p. は LT-2. No.11の 間で著しい差を認めなくなつた。

この結果は Hershey（1946）の発見した宿主域変 異 (host-range mutation) 又はLuria (1953) およ び Bertani and Weigle (1953) の発見した宿主依存 変異 (host-induced modification ないしは host-con- trolled variation）の何れかによつて生じたファージ 粒子が，No.11株でふえるためと考えられる。

TABLE 1. Efficiency of plating of phage P-22 and phage S-12 grown on Salmonella typhimurium strain LT-2 and Salmonella enteritidis strain No. 11

\begin{tabular}{c|c}
\hline Phage stock & $\begin{array}{l}\text { e.o.p. on } \\
\text { No. } 11 \text { o. p. } \\
\text { on LT-2 }\end{array}$ \\
\hline P-22 from LT-2 (No. 1) & $1.0 \times 10^{-4}$ \\
P-22 from LT-2 (No. 2) & $1.2 \times 10^{-4}$ \\
P-22 from LT-2 (No. 3) & $2.1 \times 10^{-5}$ \\
P-22 from No. 11 (No. 1) & $3.3 \times 10^{\circ}$ \\
P-22 from No. 11 (No. 2) & $3.7 \times 10^{\circ}$ \\
P-22 from No. 11 (No. 3) & $3.7 \times 10^{\circ}$ \\
S-12 from LT-2 (No. 1) & $4.3 \times 10^{-4}$ \\
S-12 from LT-2 (No. 2) & $3.3 \times 10^{-4}$ \\
S-12 from No. 11 & $1.8 \times 10^{\circ}$ \\
H-5 from LT-2 & $1.8 \times 10^{-4}$ \\
H-5 from No. 11 (No. 1) & $3.5 \times 10^{\circ}$ \\
H-5 from No. 11 (No. 2) & $3.9 \times 10^{\circ}$ \\
H-4 from LT-2 (No. 1) & $2.5 \times 10^{-4}$ \\
H-4 from LT-2 (No. 2) & $1.2 \times 10^{-4}$ \\
H-4 from No. 11 & $1.3 \times 10^{-4}$
\end{tabular}

ネズミチフス菌 LT-2株又は腸炎囷 No. 11株でふや したファージによる LT-2株およびNo.11株での導入

P-22ファージによる導入実験の結果の一部を第 2 表に示した。LT-2株でふやしたファージの titer が高 かつたので， transductant の頻度が高かつたのは当 然であるが，この表で注目されるのは LT-2株でふや したファージで No. 11株の栄養素要求変異株を recipient として導入を行つた場合，e. o. p. は上述の如 く低いにもかかわらず，導入の頻度が低くないことで ある。このことは transductant の数と，No.11での e. o. p.をもとにして計算したファージ titer との 比によつて明らかに示すことができる。すなわち， LT-2株でふやしたファージの titration をNo. 11 株 で行つたときに生じたプラックの数が，No.11株に対 する有效な導大の頻度を示すものとすれば，数百分の 一というおどろくべき高い頻度で導入が行われること になる。

しかしこのファージをNo.11原株でふやすと，LT-2， No. 11何れの株に対しても，導入の頻度が汪注等しく なり，数百分の一という様な高い頻度は得られなくな つた。そこで LT-2株でふやたたファージ液の中に含 
TABLE 2. Transduction in Salmonella typhimurium strain LT-2 and Salmonella enteritidis strain No. 11 with phage P-22 grown on either LT-2 or No. 11

\begin{tabular}{|c|c|c|c|c|c|c|c|}
\hline \multirow{3}{*}{ Recipient } & \multicolumn{3}{|c|}{ Transductants with } & \multicolumn{4}{|c|}{$\begin{array}{l}\text { Transductants per phage } \\
\text { calculated from e. o. p. }\end{array}$} \\
\hline & \multirow{2}{*}{$\begin{array}{l}\text { Phage P-22 } \\
\text { from LT-2 } \\
\text { (1) }\end{array}$} & \multirow{2}{*}{$\begin{array}{l}\text { Phage P-22 } \\
\text { from No. } 11 \\
\text { (2) }\end{array}$} & \multirow{2}{*}{$\begin{array}{l}\text { Control } \\
\text { with } \\
\text { no phage }\end{array}$} & \multicolumn{2}{|c|}{ on LT-2 } & \multicolumn{2}{|c|}{ on No. 11} \\
\hline & & & & (1) & (2) & (1) & (2) \\
\hline E-19 (No. 11, his $\left.{ }^{-}\right)$ & 1982 & 6 & 0 & $1 / 1.7 \times 10^{6}$ & $1 / 1.3 \times 10^{7}$ & $1 / 165$ & $1 / 4 \times 10^{6}$ \\
\hline $\mathrm{E}-40$ (No. $\left.11,1 \mathrm{ys}^{-}\right)$ & 76 & 4 & 0 & $1 / 7 \times 10^{6}$ & $1 / 7 \times 10^{4}$ & $1 / 700$ & $1 / 2.2 \times 10^{4}$ \\
\hline Meth-6 (LT-2, meth $\left.{ }^{-}\right)$ & 180 & 0 & 0 & $1 / 3 \times 10^{7}$ & 0 & $1 / 6.7 \times 10^{2}$ & 0 \\
\hline Try D-10 (LT-2, try $\left.{ }^{-}\right)$ & 503 & 1 & 0 & $1 / 1.1 \times 10^{7}$ & $1 / 2.2 \times 10^{6}$ & $1 / 2.4 \times 10^{2}$ & $1 / 4.5 \times 10^{6}$ \\
\hline
\end{tabular}

Titer of phage P-22 from LT-2: $\left\{1.5 \times 10^{\circ} / \mathrm{ml}\right.$ on LT-2

Titer of phage P-22 from LT-2: $\left\{4.7 \times 10^{8} / \mathrm{ml}\right.$ on No. 11

Titer of phage P-22 from No. $11:\left\{\begin{array}{l}6.6 \times 10^{10} / \mathrm{ml} \text { on LT-2 } \\ 6.6 \times 10^{6} / \mathrm{ml} \text { on No. } 11\end{array}\right.$

TABLE 3. Frequency of 1ysogenization of Salmonella tyhimurium strain LT-2 and Salmonella enteritidis strain No. 11 with phage P-22 grown on either LT-2 or No. 11

\begin{tabular}{|c|c|c|c|}
\hline Strains of bacteria and phages & $\begin{array}{l}\text { Frequency of } \\
1 \text { ysogenization }\end{array}$ & Strains of bacteria and phages & $\begin{array}{l}\text { Frequency of } \\
\text { 1ysogenization }\end{array}$ \\
\hline $\mathrm{LT}-2,10^{\circ}+\begin{array}{l}\text { phage } \mathrm{P}-22 \\
\text { from No. } 11\end{array}$ & $1 / 10$ & $\mathrm{LT}-2,10^{\circ}+$ phage $\mathrm{P}-22$ & $9 / 10$ \\
\hline LT-2, $10^{-1}+\begin{array}{l}\text { phage } \mathrm{P}-22 \\
\text { from No. } 11\end{array}$ & $3 / 10$ & $\mathrm{LT}-2,10^{-1}+\begin{array}{l}\text { phage } \mathrm{P}-22 \\
\text { from LT-2 }\end{array}$ & $9 / 10$ \\
\hline 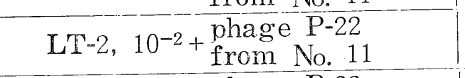 & $5 / 10$ & 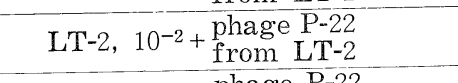 & $10 / 10$ \\
\hline 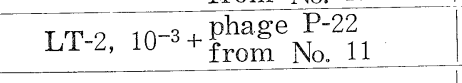 & $10 / 10$ & 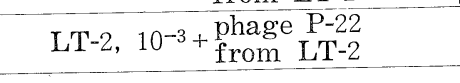 & $10 / 10$ \\
\hline Total & $19 / 40$ & Total & $38 / 40$ \\
\hline LT-2, $10^{\circ}$ (Control) & $0 / 10$ & $\mathrm{LT}-2,10^{\circ}$ (Control) & $0 / 10$ \\
\hline 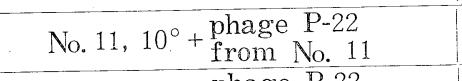 & $0 / 10$ & No. $11,10^{\circ}+\begin{array}{l}\text { phage P-22 } \\
\text { from LT-2 }\end{array}$ & $0 / 10$ \\
\hline No. $11,10^{-1}+$ phage P-22 from No. 11 & $0 / 10$ & No. $11,10^{-1}+\begin{array}{l}\text { phage P-22 } \\
\text { from LT-2 }\end{array}$ & $0 / 10$ \\
\hline 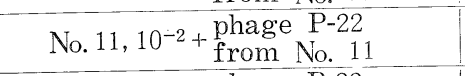 & $0 / 10$ & No. $11,10^{-2}+\begin{array}{l}\text { phage P-22 } \\
\text { from LT-2 }\end{array}$ & $0 / 10$ \\
\hline No. $11,10^{-3}+\begin{array}{l}\text { phage } \mathrm{P}-22 \\
\text { from No. } 11\end{array}$ & $1 / 10$ & No. $11,10^{-3}+\begin{array}{l}\text { phage } \mathrm{P}-22 \\
\text { from } \mathrm{LT}-2\end{array}$ & $0 / 10$ \\
\hline Total & $1 / 40$ & Total & $0 / 40$ \\
\hline No. $11,10^{\circ}$ (Control) & $0 / 10$ & No. $11,10^{\circ}$ (Control) & $0 / 10$ \\
\hline
\end{tabular}

Titer of phage P-22 from No. 11: $\begin{cases}1.5 \times 10^{9} / \mathrm{ml} & \text { on No. } 11 \\ 4.7 \times 10^{8} \mathrm{ml} & \text { on LT-2 }\end{cases}$

Titer of phage P-22 from LT-2: $\left\{\begin{array}{l}2.4 \times 10^{6} / \mathrm{ml} \text { on No. } 11 \\ 1.1 \times 10^{11} / \mathrm{ml} \text { on LT-2 }\end{array}\right.$

まれる少数の特定のファージ粒子（約 1 万分の1) の みぶNo，11株に感染してプラックをつくり，また䍡煩 度の導大を行うと考えるよりはすずてまたは大部 分のファージ粒子がNNo.11株にも感染するが，溶菌に いたらないという可能性の才が大きいと考えられる。
プラックを生じないという場合には，ファージの感染 が全く招きないか，または感染は抢きても溶菌にいた らないかの何れかであるが，この場合は後の可能性が 考えられるわけである。導入は最初 Zinder and Lederberg (1952) 功述べた様に，ファージによつて宿 
主細菌の遗伝子が相手の菌に運びこまれる現象である から，導入はとりもなおさずファージ感染のあつたこ とを意味すると考えられる。

以上の結果とほほ同じ結果が S-12 ファージについ ても得られたが，その詳細は省略する。

第2 表には， complete transduction の結果のみ を示したが, abortive transductionについても観察を 行つた. abortive transductantは minimal agar の上で極めて微小なコロニーとして認められ，Ozeki (1956) がのべている様に， minimal agar の上に 何回くりかえして分離しても, 每回 1 ケの微小なコロ ニーのみを生じた. abortive transductant は donor と phageの何れの組み合わせにおいても， complete transductant の 5 〜10倍の数が認められた。

ネズミチフス囷 LT-2 株又は膘炎菌 No. 11 株でふ やしたファージによるLT-2株むよび No. 11株の溶原 化

溶原化の頻度は第 3 表に示す如く, LT-2株は LT-2 株，No.11株の何れでふやたたファージによつても溶 原化されやすいが，No.11株は溶原化されにくく，こ とにLT-2株でふやしたファージによつては，しらべ た範囲で溶原化が全く認められなかつた。この表中， No. 11株でふやしたファージによる LT-2株の溶原化 の頻度が，LT-2 株でふやしたファージによる溶原化 の頻度に比し若干低いのは，使用したNo.11株でふえ たファージの titer が低かつたためであろう。

以上の様に導入の実験から，LT-2株でふやしたフ アージはN No.11株に感染はするが溶菌にいたらないた めに e. o. p. が低いことが想像されたが，溶原化の実 験では，感染が高い頻度でおきているという積極的な 証拠は得られなかつたわけである。そこで次の実験を 行つた.

ネズミチフス菌 LT-2株又は嗄笑 No. 11株でふや したファージを LT-2 株执よび No.11袾に方えたと きの0 (1) 抗原の生成

サルモネラにおいては，テンペレート・ファージの 感染が，新しいO抗原の生成をひきおこすことが知ら れている (Iseki and Sakai, 1953: Uetake et al. 1955).P-22ファージはO (1) 抗原の生成をひき抗 L (Zinder, 1957), Iseki and Kashiwagi (1955) のいう iotaファージの1種と考えられる。著者のシ ステムにおいて，LT-2株又はNo.11株でふやしたフ アージを LT-2 株およびNo.11株に合わせた場合， O (1) 抗原が生成されるかどうかを, Uetake et al.
（1958）の方法で検討したところ，何れの菌とファー ジの組み合わせにおいても○(1) 抗原の生成が見ら れ，O (1) 血清により強く凝集することがわかつた。 同様の結果はP-22 ファージの virulent mutantであ るH-5ファージによつても得られた。

ファージによる抗原変換ファージの genome その ものによつてひきおこされると考えられている (Iseki and Sakai, 1953) ので, LT-2株でふやしたファー ジがNo.11株において高頻度にO(1)抗原の生成をひき おこすことは，高頻度に感染がおきていることを示す と考えざるを得ない.

次にこの様にファージの感染をうけて，O (1) 抗原 を生成する様になつたNo.11株の細胞を分離培養し て，各コロニーについてO (1) 抗原をしらべると，す でに分離第 1 代において 0 (1) 抗原が全く認められな くなる。すなわち， No. 11株にLT-2株でふやした アージを感染させた際の○(1) 抗原の生成は一過性で あることがわかる。この際 Stocker (1958) が認めた 様に，プロファージが存在している細胞で $\mathrm{O}$ (1) 抗原 が一過性に生成されたり，されなくなつたりする，い わゆる，form variation が関系しているかどうかを しらべるために，分離をくりかえして，各コロニーに ついてO (1)抗原の有無をしらべたところ，全く $O(1)$ 抗原を証明できなかつた。

これに反して，溶原化されたNo.11株においては， Stocker (1958) の認めた form variation に相当す る現象が認められ，継代によつて○(1) 抗原の出没が 見られた。

ネズミチフス菌LT-2 株でふやしたファージ液に含 まれ，腸炎策 No. 11 袾でプラックをつくるファージ 粒子の本体

ネズミチフス菌 LT-2株でふやしたファージ夜に， 約 10-4の頻度で含まれ，No. 11株でプラックを作る ファージ粒于の本体については，上にものべた様に宿 主域变異か，又は宿主依存変異の何れかであると考え られる。俩主依存変異は Luria (1953) および Bertani and Weigle (1953) がのべている様に，ファー ジの genome には変化がなく，ファージが宿主細胞 でふえる間に現象型恐らく protein 部分が変化するも ので，一度もとの細胞でふやすを，完全にもとのファ 一ジに戾るものである。第1表に示した結果は，一見 宿主依存変異を示唆する様であるが，No.11株でるや したファージをLT-2株がふやした場合，単に one cycle のみでなく，多くの增列の cycleをくりかえし 
たものである。したがつてその間に selection が行わ れる可能性が充分に考えられる，そこで宿主依存変異 であるか，又は宿主域変異であるかをきめるために は，No.11株でふやしたファージをLT-2 株で one cycleのみふやして，そのファージについて性質をし らべなければならない。

その目的で，実験材料として H-5 ファージを使用 して次の実験を行つた。まづLT-2株でふやした H-5 ファージ $\left(10^{8} / \mathrm{ml}\right)$ に，No. 11株のブイヨン培養（約 $5 \times 10^{8} / \mathrm{ml}$ ) の同量を加え， $37^{\circ} \mathrm{C}$ で 20 分間振盪して 吸着せしめる。直ちに氷冷し, 冷やしながら遠心沈澱 によりブイヨンで 3 回洗桬して，遊離ファージを除い た。沈渣をブイヨンに浮游させ，LT-2怢およびNo.11 株を用いて infective center をしらべた。

その結果は LT-2株とNo.11株との間で，e.o.p.に 大差を認めず，LT-2での e.o.p./No.11での e. o. p.= 1/20であつた。したがつてNo.11株でふえたファー ジをLT-2株で one cycleのみふやしても，もとの LT-2 株でふやしたファージと同じ性質には復帰しな かつたわけで，宿主值存変異ではなくて，宿主域変異 であると考えられる。

そこで，次にこの宿主域変異株ファージが e. o.p. 以外の点に沶いて，もとのファージと異なるところが あるかぞうかをしらべた。

\section{吸着実験}

結果は第 4 表に示す如くで，何れのファージと菌の 組み合わせに拀いても大差を認めなかつた。

TABLE 4. Adscrption of phage P-22 grown on either Salmonella typhimurium strain LT-2 or Salmonella entoritidis strain No. 11 onto LT-2 and No. 11

\begin{tabular}{c|c|c|c|c}
\hline & Phage stock & Strain & \multicolumn{3}{|c}{ Phage adsorbed (\%) } \\
\cline { 2 - 5 } & $5^{\prime}$ & $10^{\prime}$ & $20^{\prime}$ \\
\hline $\begin{array}{c}\text { P-22 from } \\
\text { LT-2 }\end{array}$ & No. 11 & 85.7 & 90.1 & 90.8 \\
\hline $\begin{array}{c}\text { P-22 from } \\
\text { LT-2 }\end{array}$ & LT-2 & 87.7 & 89.2 & 89.1 \\
\hline $\begin{array}{c}\text { P-22 from } \\
\text { No. 11 }\end{array}$ & No. 11 & 81.6 & 85.2 & 87.5 \\
\hline $\begin{array}{c}\text { P-22 from } \\
\text { No. 11 }\end{array}$ & LT-2 & 79.2 & 84.8 & 88.1 \\
\hline
\end{tabular}

Titer of phage P-22 from LT-2: $1.8 \times 10^{7} / \mathrm{ml}$ Titer of phage P-22 from No. $11: 1.0 \times 10^{7} / \mathrm{ml}$

\section{一段階增殖実験}

符 1 図に示寸如く，何れのファージと菌の組み合わ
せにおいても大差を認めない。文， burst size 第 5 表の如くで，若干の差が見られるが，これらの差が 有意であるかぞうかについては結論できない。

しかしこれらの差が有意のものとすれば，上に述べ た selection の説明がこれによつて可能となるわけで ある。なお，LT-2株でふやしたファージを No. 11株 に感染させた場合は，e. o. p. が非常に低いので，一 段階增殖実験を正確に行うことはできない。

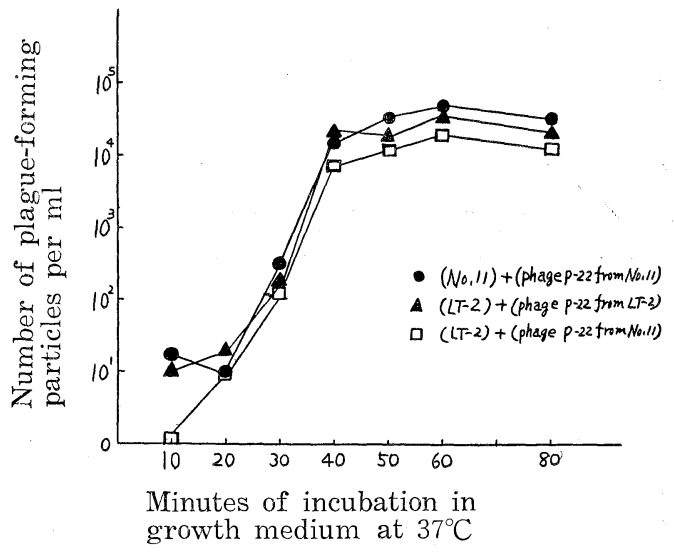

Titer of phage P-22 from LT-2: $1.7 \times 10^{8} / \mathrm{ml}$ Titer of phage P-22 from No. $11: 2.0 \times 10^{8} / \mathrm{ml}$

Fig. 1 One-step growth curve of phage P-22 grown on either Salmonella typhimurium strain LT-2 or Salmonella enteritidis srain No. 11

TABLE 5. Burst size of phage P-22 grown on either Salmonella typhimurium strain LT-2 or Salmonella enteritidis strain No. 11

\begin{tabular}{c|c|c}
\hline Phage stock & Strain & Burst size \\
\hline $\begin{array}{c}\text { P-22 from } \\
\text { LT-2 }\end{array}$ & LT-2 & 870 \\
\hline $\begin{array}{c}\text { P-22 from } \\
\text { No. 11 }\end{array}$ & LT-2 & 659 \\
\hline $\begin{array}{c}\text { P-22 from } \\
\text { No. } 11\end{array}$ & No. 11 & 764 \\
\hline
\end{tabular}

Titer of phage P-22 from LT-2: $1.7 \times 10^{8} / \mathrm{ml}$ Titer of phage P-22 from No. $11: 2.0 \times 10^{8} / \mathrm{ml}$

\section{考察}

以上の実験は，序においてのべた様に，偶然の機会 から始められたものであるが，ネズミチフス菌LT-2株 でふやしたP-22 ファージまたは，S-12 ファージに 
は，約10-4の頻度でNo.11株でプラックをつくるファ 一ジ粒子が含まれることがわかつた。その他の大多数 のファージ粒子は，No.11株にも感染はするが，溶菌 にも溶原化にもいたらないと考えられる。感染がおき ていることは，埒入がかなりの頻度に見られることに よつて推定され，さらにO (1) 抗原の生成が高頻展に 認められることから結論される。文，LT-2怢でふや したファージ中に含まれ，No. 11株でプラックをつく るファージ粒子は，LT-2侏で one cycleふやしても， もとのファージと同じ e. o. p. を示す様にならない ので，宿主依存変異ではなくて，宿主域変異と考えら れる。この宿主域変塂株ファージは，もとの野生型フ アージと比して，LT-2株，No.11株に対する e.o.p. が異なる他は，吸着能，潜伏期，burst size などに は著しい差が認められなかつた。

Zinder (1953) はP-22 ファージがネズミチフス菌 を宿主としたときに，宿主依存变異をおこして Salmonella gallinarum での e. o. p. が低くなることを のべこのときにも導大が行われるとのべているが， 彼の結果は Luria（1953）によつて簡単に引用され ているもので，詳細は報告されていない。この場合， 宿主域変異か宿主依存変異かの検討がなされたかどう かも不明である。

LT-2株でふやした野生型ファージがNo. 11株に感染 するにもかかわらず，溶菌ないしは溶原化にいたらな いのは，いかなる理由によるものであろうか。ファー ジの感染の際には, 宿主細胞に注入されるのは, 主に フォージのDNAであり(Hershey and Chase, 1952), 又極く微量の蛋白質も同時に注大されることがわかつ ている (Mahler and Fraser, 1959). しかもこの微 量の蛋白質がファージ感染の成立において重要な役割 を演ずることが知られている (Mahler and Fraesr, 1959 ; 木方ら，1959). 著者の実験により，野生型フ アージがNo.11株でふえる様になるのは宿主域変異で あることがわかつたので，この際は特に上述の微量蛋 白質の役割に注目する必要はないかも知れない。

野生型ファージのNo.11株感染の場合, vegetative multiplication が全くおこなわれないかどうかについ て考えて見たい，導入が行われるためには特に vegetative multiplication を必要としないと考えられる

(Bertani, 1958) が，溶原化の成立には vegetative multiplication が一般に先行するとされる (Luria et al., 1958). 著者の野生型ファージのNo. 11株感染の 場合は，恐らく vegetative multiplication が全くお
きていないのではあるまいか。最近中川（1960）らに よつて, サルモネラ $\mathrm{E}_{2}$ 群の S. selandia, S. Kinshasa および Escherichia freundiiが $\varepsilon^{34}$ ファージを吸着 し，核酸の注入をうけるが，殺菌も溶菌も溶原化もお こさないにもかかわらず，核酸の注入をうけた細胞は 一過性に抗原34を生成することを報告したが，著者の 報告した現象はこれに類似したものと考えられる。

Uetake et al. (1958) はテンペレート・ファージ の virulent mutant の感染によつても，溶菌に先立 つて新しい抗原の生成がおこることを報告したが，著 者の実験においても P-22の virulent mutant である H-4，H-5 ファージにおいても， O (1) 抗原の生成が 見られた。しかし，著者のシステムで LT-2株でふや したファージをNo.11株に感染させた場合はこれら virulent mutantの感染によつても，溶菌がおきない のであるから，Uetake et al. (1958) の報告とはや や異なるわけであり，LT-2株でふやしたファージを LT-2株に感染させた場合が，Uetake et al.（1958） の報告に相当するわけである。

\section{総括}

ネズミチフス菌LT-2株でふやしたP-22 ファージお よび S-12ファージは，腸炎菌No.11株に対して約 10-4の e. o. p.をもつにもかかわらず，導入の頻度は LT-2株，No.11株の何れを recipientにしてもほ ほ等しいことがわかつた。大多数のファージ粒子は No. 11株で溶菌をおこさないのみならず，溶原化もお こさない．しかし，O (1) 抗原の生成は高い頻度で認 められるので，感染はおこなわれると考えられる。

LT-2 株でふえたファージのうち，No. 11株に溶菌な いしは溶原化をひきおこすファージ粒子は宿主依存変 異ではなくて，宿主域変異株であると考えられる。

\section{謝辞}

稿を終るに臨み，御眃篤なる御指導及び御校閲を賜 つた恩師牛場大蔵教授に深甚の謝意を捧げる。また終 始多大なる御援助を頂いた渡辺力講師その他教室員各 位に深く感謝する。

\section{交献}

1) Adams, M. H. : Methods of study of bacterial viruses. Methods of Medical Research (I. H. Comroe, editor), Chicago, The Year Book Publishers, 2, 1, 1950. 2) Adams, M. H. : Bacteriophages. Interscience Publishers, New York-London, 1959. 3) Bertani, G., and Weigle, 
J. J.: Host-controlled variation in bacterial viruses. J. Bacteriol., 65, $113 \sim 121,1953 . \quad 4$ ) Bertani, G. : Lysogeny. Advances in Virus Research., 5, 151-193, $1958 . \quad 5)$ Davis, B. D., and Mingioli, E. S.: Mutants of Escherichia coli requiring methionine or vitamin $B_{12}$. J. Bacteriol., 60, 17-28, 1950. 6) Demerec, M. et al.: Genetic studies with bacteria (Carnegie Institution of Washington Publication 612), $1956 . \quad 7)$ Hershey, A. D. : Spontaneous mutants in bacterial viruses. Cold Spring Harb. Symp. Quant. Biol., 11, 67-76, 1946. 8) Hershey, A. D., and Chase, M. : Independent functions of viral protein and nucleic acid in growth of bacteriophage. J. Gen. Physiol., 36, 39-56, 1952. 9) Mahler, H. R., and Fraser, D.: Studies in partially resolved bacteriophage-host systems IV. Some properties of the protoplast-infecting agent derived from T2 bacterichage. Virology, 8, 401 424, 1959. 10) Iseki, S., and Sakai, T.: Artificial transformation of $\mathrm{O}$ antigens in Salmonella E grcup. II. Antigen-transforming factor in bacilli of subgroup E2. Proc. Japan Acad., 29, 127-131, 1953. 11) Iseki, S., and Kashiwagi, K. : Induction of somatic antigen 1 by bacteriophage in Salmonella B group. Proc. Japan Acad., 31，558-563，1955. 12）木方行郎, 春名一郎, 渡 边格: プロトプラストーT2-DNA 系に於けるファー ジ増殖の2, 3 の問題について。Virus, 10, 203, 1960.
13) Luria, S. E. : Host-induced modifications of viruses. Cold Spring Harb. Symp. Quant. Biol., 18, 237-244, 1953. 14) Luria, S. E., Fraser, D. K., J N., and Burrous, J. W. : Lysogenization, transduction, and genetic recombination in bacteria. Cold Spring Harb. Symp. Quant. Biol., 23，71-82，1958. 15）中川昭久, 内田孝宏, 植竹 久雄, 牧野利一: : 溶菌も溶原化も起さぬファージ感 染。Virus, 10, 274-279, 1960. 16) Ozeki, H. : Abortive transduction in purine-requiring mutants of Salmonella typhimurium. Genetic studies with bacteria (Carnegie Institution of Washington Publication 612), 97-106, 1956. 17) Stocker, B. A. D.: Lysogenic conversion by the A phages of Salmorella typhimurium. J. Gen. Microbiol., 18, ix, 1958. 18) Uetake, H., Nakagawa, T., and Akiba, T.: The relationship of bacteriophage to antigenic changes in group $\mathrm{E}$ salmonellas. J. Bactericl., 69, 571-579, $1955 . \quad 19)$ Uetake, H., Luria, S. E., and Burrcus, J. W. : Conversion of somatic antigens in Salmonella by phage infection leading to 1ysis or 1ysogeny. Virology, 5, 68-91, $1958 . \quad 20)$ Zinder, N. D,. and Lederberg, J. : Genetic exchange in Salmonella. J. Bacteriol., 64, 679-699, 1952. 21) Zinder, N. D. : Cited in Luria, S. E. Cold Spring Harb. Symp. Quant. Biol., 18, 237-244, 1953. 22) Zinder, N. D.: Lysogenic conversion in Salmonella typhimurium. Science, 126, 1237, 1957. 